\title{
MANAGEMENT OF FERMENTATION PROCESS IN ENSILAGED LIVESTOCK FEED
}

\author{
B. Dinić ${ }^{1}$, N. Đorđević ${ }^{2}$, B. Anđelković ${ }^{1}$, D. Sokolović ${ }^{1}$, D. Terzić ${ }^{1}$ \\ ${ }^{1}$ Institute for Forage Crops, Trg Kosturnice 50, 37000 Kruševac, Republic of Serbia \\ ${ }^{2}$ Faculty of Agriculture, University of Belgrade, Nemanjina 6, 11080 Zemun, Republic of Serbia \\ Corresponding author: bora.dinic@ikbks.com \\ Review paper
}

Abstract: The control of fermentation process in ensilaged livestock feed is based on the knowledge of biomasses. The important aspects are the suitability for ensilaging (the content of fermentative carbohydrates and buffer capacity of the biomass), providing of the correct level of dry matter and anaerobic environment, wilting, using the chemical additives such as organic acids and their salts, using of biologic additives (inoculants), adsorption of mycotoxins, etc. In purpose of making the process of ensilaging of grasses, legumes and grass-legume mixes, the silages are prepared as bales or silo-tubes.

Key words: silage, carbohydrates, buffer capacity, wilting, carbohydrate feed, inoculants

\section{Introduction}

Hay and silage are the main forms of conserved bulk feed. The quality of hay is influenced by weather conditions. This has led to the lesser usage of hay and to increased usage of silages. Hay is, before all, more expensive feed, but the minimal quantities are required for the complex digestive tract of ruminants. In many countries, there is the trend of preparing and using the higher amounts of silages than hay (Wilkinson and Toivonen, 2003).

The control of the fermentation process is based on the wilting, using of chemical additives (organic acids and their salts), using of biological additives, increasing of the aerobic stability of silages, using mycotoxins, etc. (Đorđević and Dinić, 2003). In purpose of making the process of ensilaging of grasses, legumes and grasslegume mixes, the silages are prepared as bales in Europe and silo-tubes in America.

Today, the biological additives (bacterial-enzyme inoculants) are currently the most used. They are used in purpose of intensifying fermentation in plant material which is hard to ensilage and, also, in purpose of increasing the anaerobic This paper was presented at $9^{\text {th }}$ International Symposium "Modern Trend in Livestock Production" on 7-9 October 2009, Belgrade-Zemun, Republic of Serbia. 
stability in corn silage, which is the most used silage type in the world (Đorđevic et al., 2006). The hetero fermentative lactic acid bacteria Lactobacillus buchneri are included in the latest generation of enzyme inoculants (Driehuis et al., 2005).

To gain the maximum quality and nutrient value the knowledge of technology for bulk feed conservation is very important. The conservation of nutrient quality is gained by using the modern mechanization, chemical and biological additives. However, the basic of these principles is to acknowledge all of these factors that have influence to quality and nutrient value of bulk feed.

\section{Factors that have influence on fermentation process}

Ensilaging is the process of conserving the plant biomass and byproducts using the lactic acid. The lactic acid in this process is either the product of the natural micro flora or the added (inoculated) lactic acid bacteria varieties.

The process of the lactic acid fermentation process is influenced by chemical composition of biomass (the content of water soluble carbohydrates and the buffer capacity).

\section{Water soluble carbohydrates (sugar) and the buffer capacity}

Corn, sorghum, etc. are the forage crops that can ferment very well, and by using the correct silage techniques quality silages can be made. This forage crops are characterized by high carbohydrate content and low protein content. Due to high carbohydrate reserves, the enough lactic acid is produced during the first couple of days. The $\mathrm{pH}$ indicator decreases to less than 4, and the lactic acid fermentation is stopped.

Alfalfa is one of forage crops that are hard for ensilaging. It contains low quantities of carbohydrates and high quantities of protein. Due to low carbohydrate content, low amount of lactic acid can be produced. That quantity of lactic acid is insufficient for decreasing $\mathrm{pH}$ enough for butyric fermentation to stop. The produced lactic acid, in this case, is converted to butyric acid. In the same time the intensive decomposition of proteins and amino acids occurs. As the result of these processes $\mathrm{pH}$ of the silage increases and the silage spoils (Dinić et al., 1998).

The decreasing of $\mathrm{pH}$ in the lactic acid fermentation process depends, mostly, on the carbohydrate content in green mass. The carbohydrate content is different in the different plants. By carbohydrate content the total quantity of hydro soluble fermentative carbohydrates ( $\mathrm{g} \mathrm{kg}^{-1} \mathrm{DM}$ (dry matter)) The possible level of biological acidification depends on the content of constituent matter of feed and on the resistance it gives to $\mathrm{pH}$ decreasing.

This trait is called the buffer capacity. The buffer capacity is defined as the amount of lactic acid required to make silage mass acidic to $\mathrm{pH} 4$ (Weissbach, 
1967). It is measured in meqv of lactic acid per $100 \mathrm{~g}$ DM. For the determination of buffer capacity the method by Playne and Mc Donald (1966) is used. By this method the chopped mass is first titrated with the solution of $\mathrm{HCl}$ with concentration of $0.1 \mathrm{~mol} / 1$ until the $\mathrm{pH} 3$ for the removing of bicarbonates (as carbon dioxide), and then is titrated again with $\mathrm{NaOH}$ with concentration of 0.1 $\mathrm{mol} / \mathrm{l}$ until $\mathrm{pH}$ 6.00. The buffer capacity is defined as meqv of base required to change the $\mathrm{pH}$ from 4.00 to $6.00 \mathrm{in} 1 \mathrm{~kg}$ DM.

The silage suitability of plants can be precisely determined based on the ratio of carbohydrates (S- sugars) and the buffer capacity (BC) (Dinić et al., 1998). If the present sugars were used for lactic acid production with $100 \%$ efficiency, the carbohydrates and buffer capacity ratio $(\mathrm{S} / \mathrm{BC})$ would be 1.00 . However, in practice, only $50 \%$ is used for lactic acid production, meaning the $\mathrm{S} / \mathrm{BC}$ ratio must be significantly higher than 1.00 .

\section{Level of dry matter}

The quantity of dry matter in silo mass is one of the most important factors for the amount of losses of the dry matter and for the directing the fermentation process in the silo mass, especially when the silo mass is rich in protein and minerals (Dinić, 1990, Dinić, 1997). The increasing of the amount of dry matter in silo mass is accomplished by wilting. The wilting, or short-term drying, is the least expensive solution for the successful ensilaging of perennial legumes and grasses biomass.

The lactic acid bacteria are able to remain active in the environment with increased osmotic pressure, while most other anaerobic microorganisms can not compete with them. The osmotic pressure is the force of attraction of water molecules by the concentrated solutions in relation to the less concentrated solution.

A lot of researchers worked on the issue of silo mass wilting, but the most complex studies were performed under the direction of Zimmer and Wilkins (1984), whose general conclusions are that the silages, in general, were well kept in the two treatments in which the preserving agents, in silage from non wilted silo mass, were based on formic acid and when the wilted silo mass had a 30-40\% of dry matter.

The proportion $\mathrm{S} / \mathrm{BC}$ depends on the content of dry matter in ensilaged material. If the level of dry matter is lower, the proportion of $\mathrm{S} / \mathrm{BK}$ has to be higher in order to provide a stable $\mathrm{pH}$ values (Table 1).

Table 1. The dependence of the critical pH value on the dry matter content (Beyer et al., 1982)

\begin{tabular}{|l|l|l|l|l|l|l|l|l|}
\hline Dry matter, $\mathrm{g} \mathrm{kg}^{-1}$ & 150 & 200 & 250 & 300 & 350 & 400 & 450 & 500 \\
\hline Stabile silage in $\mathrm{pH}$ & 4.10 & 4.20 & 4.35 & 4.45 & 4.60 & 4.75 & 4.85 & 5.00 \\
\hline
\end{tabular}


In particular proportion of $\mathrm{S} / \mathrm{BC}$, the fermentation is even better if the level of DM is higher. Beyer et al. (1982) found the minimal content of DM, which provides the silage without butyric acid. For calculating the minimum content of $\mathrm{SM}(\mathrm{Y})$ the next formula is used:

$$
\mathrm{Y}\left(\mathrm{g} \mathrm{kg}^{-1}\right)=450-(80 \mathrm{x} \check{\mathrm{S}} / \mathrm{PK}) \text {. }
$$

To get the silage without the butyric acid, during the process of alfalfa ensilaging the minimal content of DM be $413 \mathrm{~g} \mathrm{~kg}^{-1}$ in the proportion of S/BC of 0.46 , and in the proportion of $\mathrm{S} / \mathrm{BC}$ of 0.75 requires a minimum content of the $\mathrm{DM}$ $390 \mathrm{~g} \mathrm{~kg}^{-1}$ (Table 2).

Table 2. Ensilability of alfalfa biomass from second cut, , $\mathrm{g} \mathrm{kg}^{-1} \mathrm{SM}$ (Dinić, 1997)

\begin{tabular}{|l|c|c|c|c|l|}
\hline \multirow{2}{*}{ Chemical parameters } & \multicolumn{2}{|c|}{ Beginning of budding $\left(\mathrm{b}_{1}\right)$} & \multicolumn{2}{|c|}{ Beginning of flowering $\left(\mathrm{b}_{2}\right)$} & \multirow{2}{*}{ Significance } \\
\cline { 2 - 5 } & Fresh $\left(\mathrm{c}_{1}\right)$ & Wilted $\left(\mathrm{c}_{2}\right)$ & Fresh $\left(\mathrm{c}_{1}\right)$ & Wilted $\left(\mathrm{c}_{2}\right)$ & \\
\hline Dry mass & 170.7 & 303.7 & 234.3 & 373.7 & $(\mathrm{~B}, \mathrm{C})^{* *}$ \\
\hline Sugar & 52.7 & 69.9 & 54.5 & 73.1 & $(\mathrm{~A}, \mathrm{~B}, \mathrm{C})^{* *}$ \\
\hline BC & 114.7 & 117.3 & 116.0 & 97.3 & $\mathrm{~B} * *$ \\
\hline Ratio S/BC & 0.46 & 0.61 & 0.47 & 0.75 & $(\mathrm{~A}, \mathrm{~B}, \mathrm{C})^{* *}$ \\
\hline Min. Content of DM & 413 & 402 & 412 & 390 & \\
\hline
\end{tabular}

A -Cut; B - Phase of plant evolution; C - Level of dry matter

\section{Anaerobic conditions of environment}

The most important condition for conserving, both natural and spontaneous fermentation, is to provide anaerobic environment (McDonald, 1985). The anaerobic conditions of the environment are necessary to eliminate a number of strains of decay causing microorganisms whose activity requires the presence of oxygen. In practice, anaerobic conditions may be provided in several ways. The best way is to store and keep food in the pressurized closed facilities (siloharvesters). In such facilities, oxygen which is came with the silo mass and which was present in the building is quickly spent on the activity of plant enzymes. In the open type silos (silo-trench) the possibility of providing anaerobic environment depends on the quality of compression of silo mass and on the quality of closing with the plastic foil and the type of material that is used for pressing.

Quality of compression depends on the fineness of chopping, or on the length of the bits, and the length of the bits depends on the content of dry matter in the silo mass. The chopping of silo mass has the positive influence on the production of lactic acid and $\mathrm{pH}$ values (Nehring, 1959). The chopping, also, contributes to the decreasing of heating of the silage, and provides greater stability (Murdoch et al., 1955). Cobic et al. (1983) state that the green alfalfa with the moisture proportion more than $80 \%$ should be chopped to bits about $20 \mathrm{~cm}$ in length, while the material with $70 \%$ or less moisture should be chopped to $2.5 \mathrm{~cm}$ 
bits. Fine chopping of the plants with high moisture and their compression brings to the large losses in the form of sap (eufluenta). Due to that, the high-valued nutritional substances are lost. In such environment, besides the lactic acid fermentation, the butyric (undesirable) fermentation is, also, present. Then, besides lactic acid, butyric acid, ammonia and other undesirable products are created. Silage from such materials are not suitable for livestock feed and are evaluated with low marks and get classified in the lower classes. To support these claims, results are presented in Table 3.

Table 3. Silage quality, density and DM losses in round bales produced from a grass crop wilted for 24 hours either wide-spread or in swaths (Spörndly and Pauly, 2008)

\begin{tabular}{|c|c|c|c|c|c|}
\hline \multirow[b]{2}{*}{ Chemical parameters } & \multicolumn{2}{|c|}{ Wide-spread } & \multicolumn{2}{|c|}{ Swathed } & \multirow[t]{2}{*}{ Sign. $(\mathrm{P}<)$} \\
\hline & Mean & SD & Mean & SD & \\
\hline DM content, g kg-1 & 416 & 24.2 & 285 & 17.2 & 0.001 \\
\hline $\mathrm{pH}$ & 5.2 & 0.09 & 4.8 & 0.13 & 0.001 \\
\hline $\mathrm{NH}_{3}-\mathrm{N}\left(\mathrm{g} \mathrm{kg}^{-1} \mathrm{~N}\right)$ & 65.1 & 11.38 & 109.6 & 14.87 & 0.001 \\
\hline WSC, $\mathrm{g} \mathrm{kg}^{-1} \mathrm{DM}$ & 86.0 & 11.92 & 43.2 & 15.33 & 0.001 \\
\hline Lactic acid, $\mathrm{g} \mathrm{kg}^{-1} \mathrm{DM}$ & 15.4 & 4.69 & 39.6 & 10.74 & 0.001 \\
\hline Acetic acid, $\mathrm{g} \mathrm{kg}^{-1} \mathrm{DM}$ & 3.6 & 0.90 & 8.8 & 2.89 & 0.001 \\
\hline Butyric acid, $\mathrm{g} \mathrm{kg}^{-1} \mathrm{DM}$ & 0.4 & 0.08 & 7.3 & 4.35 & 0.001 \\
\hline Ethanol, $\mathrm{g} \mathrm{kg}^{-1} \mathrm{DM}$ & 12.2 & 3.35 & 14.7 & 2.54 & 0.001 \\
\hline 2.3-butanediol, $\mathrm{g} \mathrm{kg}^{-1} \mathrm{DM}$ & 3.1 & 0.56 & 13.9 & 3.21 & 0.001 \\
\hline Density, $\mathrm{kg} \mathrm{DM} \mathrm{m}^{-3}$ & 181 & 12.8 & 137 & 9.7 & \\
\hline DM loss, $\%$ of initial DM & 1.9 & 0.61 & 4.5 & 12.8 & \\
\hline
\end{tabular}

Based on the results in the table 3, it can be seen that the wilting was significantly faster in the wide-spread biomass than in the swathed biomass. The higher content of DM was established for $131 \mathrm{~g} \mathrm{~kg}^{-1}$ (416:285 $\left.\mathrm{g} \mathrm{kg}^{-1}\right)$, which contributed to the lesser degradation of protein in the process of ensilaging $\left(\mathrm{NH}_{3}-\mathrm{N}\right.$ $65.1: 109.6 \mathrm{~g} \mathrm{~kg}^{-1} \mathrm{~N}$ ) and better preservation of sugar in ensilaged biomass (WSC $\left.86.0: 43.2 \mathrm{~g} \mathrm{~kg}^{-1} \mathrm{DM}\right)$.

It can, also, be seen that there is a big difference in the content of butyric acid in the silage. The biomass that was wide-spread after cutting had butyric acid in traces $\left(0.4 \mathrm{~g} \mathrm{~kg}^{-1} \mathrm{SM}\right)$, while the silage made from swathed biomass had up 18 times higher content of the butyric acid (0.4: $\left.7.3 \mathrm{~g} \mathrm{~kg}^{-1} \mathrm{DM}\right)$. It should be noted that similar observations, also, apply to 2.3-butanediol ( Table 3). Losses of dry matter in the silage made from biomass in the swath are over two times higher (4.5: $1.9 \mathrm{~g}$ $\mathrm{kg}^{-1} \mathrm{SM}$ ) in relation to the wide-spread biomass, although, those losses can not be considered great. 


\section{The use of additives}

Many modern farmers consider that it is easy to control the process of fermentation, due to accessibility of the large number of additives (Spörndly and Pauly, 2008). The possible additives are carbohydrate feeds, chemical additives (organic and inorganic acids and their salts) and inoculates combined with enzymes.

\section{The use of carbohydrate additives}

The most favorable, in the conditions of Serbia, are the carbohydrate additives (miscellaneous grain crops meals). They are used in the biomasses that are hard to ensilage (biomasses of perennial and annual legumes). Grain meal is the additive that can be, without many difficulties, produced in every farm. It is easy to dose and to apply in the plant mass. It has the positive effect on the total nutrient value of the silage, and, also, decreases the level of moisture of the ensilaged material and the draining of the plant sap.

The doses of $4-10 \%$ are recommended. In the experiments and in practice, the most used is maize meal, due to the high accessibility to that feed (Dinić et al., 1996, Djordjevic et al., 2000a). As the carbohydrate feed, the by-product of sugar industry (molasses and the dry chopped beet) can be used. Molasses is one of the by-products of sugar industry and potentially the most important additive for the legumes ensilaging. It contains about $80 \%$ of dry matter, of which the $45-50 \%$ is saccharose. Recommendations for the amount that is used in the silage, depending on the author, are $0,5-6 \%$ in comparison to the green mass, and which must be diluted with water in relation 1: 1 to 1: 3 , due to viscosity of molasses. Due to the confluence of the solution in the bottom third of the silo should be added a half of molasses dose, in the second third the entire dose, and in the top third one and a half dose.

In the experiment of Dinić et al. (1996), the alfalfa from the second cut was ensilaged with addition of corn meal (2, 4 and $6 \%)$, molasses $(1,2$ and 3\%) and formic acid $(0.15,0.30$ and $0.45 \%)$. All silages with different additives were of better quality and received greater number of points (by Zelter) compared to the control alfalfa silage. According to the effects, in terms of $\mathrm{pH}$ value and the amount of lactic acid, molasses was not behind the formic acid. These carbohydrate feeds, besides of providing favorable relations $\mathrm{S} / \mathrm{BC}$, also provide a favorable ratio of protein and energy in the silage. 


\section{The chemical conservation}

Chemical conservation of plants is based on the theory of inhibition of the enzymes. The numerous experiments are performed in order to study the problems of chemical conservation. In those experiments different preservatives and different doses are used. Although there are practical recommendations for doses of the preserving agents, it is considered that they are primarily conditioned by the dry matter content. Taranov (1982) considers that the optimal dose of preserving agents is in relation to the content of moisture in the interval $60-70 \%$. Each increase of moisture outside of this interval for $1 \%$ requires for the dose of preserving agents increase for $1 \%$. The reduction of moisture below the limit to $40 \%$ requires increasing doses of preserving agents for $0.5 \%$ for each moisture percent. For materials with humidity lesser than $40 \%$ is not recommended to further increase the amount of preserving agents. However, there are authors who believe that the use of chemical preserving agents is justified only for the material with very high percentage of moisture.

Today, the use of chemical preserving agents is mostly abandoned, as for the cost, and due to the possible negative effects on the health of the animals.

\section{The use of the bacterial inoculates}

The main goal of the inoculation is the addition of the selected strains of homo fermentative lactic bacteria to intensify and direct fermentation, primarily in the feeds that does not contain enough fermentable carbohydrates, or are, due to thermal treatment, practically sterile. The advantages of biological additives are, above all, that they do not leave residua and do not negatively affect the health of animals and the quality of their products. For these reasons, their use increasingly replaces the use of chemical preserving agents, regardless of their efficiency.

The main reason that led the scientists on the use of bacterial inoculants is the small number of epiphyte lactic acid bacteria on the live plants, which is only $10-10^{2}$ bacteria per gram of the green mass (Jambor and Šiške, 1997). In contrast, the number of enterobacteria is far higher, by $10^{2}-10^{7}$ per gram. Due to the large numeric differences, lactic acid fermentation runs slow even by providing the optimal initial conditions, which results in achieving the silage of lower quality. In the practice, the bacterial inoculants are used as both dry or in the form of solutions, and under different commercial names (Microsil, Lactisil, Sila-Bac, Silall, Biostabil, etc.). Before the use of dry preparations are diluted in the small amount of water and are sprayed uniformly on the mass prepared for the ensilaging.

The propionic acid is known as the very effective fungicide, and is used to conserve unripe corn grains in conditions of the presence of air. This encouraged 
the researchers to examine the idea of the possibility of using propionic acid bacteria as the inoculants in order to increase the aerobic stability of silages. Thus, for example, Dawson et al. (1998) inoculated the high moisture corn during the ensilaging with the bacteria Propionibacterium acidipropionici and determined the improvement of fermentation and aerobic stability.

As the stimulators of the lactic acid fermentation in the process of the ensilaging, the enzyme supplements containing cellulase, hemicelulaze, amylases, pectinase and ligninase are used. By the activities of the mentioned enzymes the crude cellulose is decomposed, and the final products are carbohydrates with the lower molecular mass, which can serve as a substrate for lactic acid bacteria activity (Đordjević et al., 1998a).

The principle of the activity of the cellulase enzymes is particularly important when ensilaging alfalfa and red clover, which does not contain a sufficient amount of fermentable carbohydrates. The effect of the use of cellulolytic enzymes is especially seen in the simultaneous use of inoculates of homo fermentative lactic acid bacteria. For this reason, an increasing number of commercial biological preparations that are produced as additives for ensilaging contain, besides the selected strains of lactic acid bacteria, the cellulolytic supplements.

The problem with well conserved silages ensilaged using homo fermentative lactic inoculants is reduced aerobic stability compared to the uninoculated silages. Merry et al. (1997) state that acetic, bytiric, especially propionic acid have larger fungicide effect than lactic acid, and are even desirable in the silage certain quantities. Due to this hetero fermentative lactic acid bacteria can have a positive significance for the aerobic stability of silage. Accordingly, Elferink et al. (1997) used obligate or facultative hetero fermentative lactic acid bacteria as inoculants in the ensilaging of corn. Due to this the highest aerobic stability was achieved with the inoculate Lactobacillus buchneri, and to a lesser extent, with L. kefir and L. parabuchneri, while other studied obligate or facultative heterofermentative lactic acid bacteria did not increase, or even reduced aerobic stability of silage (L. graminis, L. plantarum).

\section{Conclusion}

The control of fermentation process is based on the wilting, or the increase of the content of dry matter in silo mass to at least $300-400 \mathrm{~g} \mathrm{~kg}^{-1}$. It is important to gain the knowledge of the biomass from the aspect of suitability for ensilaging, meaning the determination and providing the favorable proportion of sugar and buffer capacity. This can be achieved trough the use of chemical supplements from the organic acids and their salts, the use of biological additives, inoculants in the combination with enzymes (amylases, cellulase, hemicellulase, etc.) and using of 
inoculates in order to ensure aerobic stability of silage, with the addition of homo fermentative and hetero fermentative bacteria, as well as the additives that inhibit the development of mold and yeasts.

\title{
Načini upravljanja procesom fermentacije u siliranim hranivima
}

\author{
B. Dinić, N. Đorđević, B. Anđelković, D. Sokolović, D. Terzić
}

\section{Rezime}

Kontrola procesa fementacije bazira se na poznavanju biomasa u pogledu pogodnosti za siliranje, odnosno obezbeđivanju povoljnog odnosa šećera i pufernog kapaciteta. Biomase višegodišnjih leguminoza i trava neophodno je provenjavati, odnosno povećati sadržaj suve materije u silomasi na najmanje 300$400 \mathrm{~g} \mathrm{~kg}^{-1}$. Za teško silirajuće biomase (višegodišnje i jednogodišnje leguminoze) koristiti ugljenohidratna hraniva (kukuruzna prekrupa, prekrupa ostalih žitarica, suvi rezanci šećerne repe, melasa, i dr.). Korišćenje hemijskih sredstava iz reda organskih kiselina i njihovih soli. Upotreba bioloških dodataka, inokulanata u smeši sa enzimima (amilaze, celulaze, hemicelulaze i dr.) obezbeđuje dobijanje dobre i stabilne silaže, kao i silaže veće hranljive vrednosti. Korišćenje inokulanata sa homo $\mathrm{i}$ heterotrofnim mikroorganizmima u cilju obezbeđivanja aerobne stabilnosti silaža, posebno lakosilirajućih biomasa (kukuruza, sirka, sudanske trave, italijanskog ljulja i dr.).

\section{References}

BEYER M., CHUDY A., HOFFMAN B., HOFFMAN L., JENTSCH W., LUDDECKE F., SCHIEMANN R., SCHMIDT L., WEISSBACH F. (1982): Применение комплексной системы оценки кормов в растениводстве. Таблица кормов для крупного рогатого скота (Перевод с немецкого). Колос, Москва, 209-267.

ČOBIĆ T., BAČVANSKI S., VUČETIĆ S. (1983): Proizvodnja i korišćenje silaže u ishrani stoke. Nolit, Beograd.

DAWSON T.E., RUST R.S., YOKOYAMA M.T. (1998): Improved fermentation and aerobic stability of ensiled, high moisture corn with the use of Propionibacterium acidipropionici. Journal of Dairy Science, 81, 1015-1021.

DINIĆ B. (1990): Uticaj provenjavanja silo-krme crvene deteline i konzervansa na kvalitet silaže. Arhiv za poljoprivredne nauke. 51, 183, 235-244. 
DINIĆ B., KOLJAJIĆ V., STOŠIĆ M., IGNJATOVIĆ S., LAZAREVIĆ D. (1996): Korišćenje ugljenohidratnih hraniva i mravlje kiseline za konzervisanje lucerke. VIII jugoslovenski simpozijum o krmnom bilju. Zbornik radova, 26, 491-497.

DINIĆ, B. (1997): Uticaj faze razvića biljaka, nivoa suve mase i hemijskog konzervansa na kvalitet i hranljivu vrednost silaže lucerke. Poljoprivredni fakultet, Univerzitet u Beogradu.

DINIĆ B., KOLJAJIĆ V., ĐORĐEVIĆ N., LAZAREVIĆ D., TERZIĆ D. (1998): Pogodnost krmnih biljaka za siliranje. Savremena Poljoprivreda. 1-2, 154-162.

DINIĆ B., ĐORĐEVIĆ N., (2005): Pripremanje i korišćenje silaže. Priručnik. Institut za istraživanje u poljoprivredi SRBIJA, Vizartis, Beograd.

DINIĆ B., ĐORĐEVIĆ N., RADOVIĆ J., IGNJATOVIĆ S. (2005): Modern procedures in technology of conserving lucerne by ensiling. Biotechnology in Animal Husbandry, 21, 5-6, 297-303.

ĐORĐEVIĆ N., KOLJAJIĆ V., DINIĆ B. (1998): Korišćenje enzimskih dodataka kao stimulatora ili inhibitora aktivnosti mikroorganizama u silaži. Savremena Poljoprivreda, 1-2, 149-154.

ĐORĐEVIĆ N., GRUBIĆ G., ADAMOVIĆ M. (2000): Influence of wilting, inoculant and carbohydrate additives on lucerne silage quality. 51th Annual Meeting of EAAP. The Hague, 21-24 August 2000. Abstract, 168.

ĐORĐEVIĆ N., DINIĆ B. (2003): Siliranje leguminoza. (Monografija). Institut za istraživanje u poljoprivredi SRBIJA, Vizartis, Beograd.

ĐORĐEVIĆ, N., GRUBIĆ, G., POPOVIĆ, Z., DINIĆ, B., PANDUREVIĆ, T. (2006): Uticaj bioloških i ugljenohidratnih dodataka na kvalitet silaže lucerke. XI savetovanje o biotehnologiji, Čačak, 3.-4. mart 2006.godine. Zbornik radova. 11, II, 11-12, 479-485.

ĐORĐEVIĆ N., DINIĆ B. (2007): Hrana za životinje. Monografija. Aranđelovac. Cenzone Tech Europe.

DRIEHUIS F., GIFFEL M.C. (2005): Butyric acid bacteria spores in whole crop maize silage. Proceedings of the XIV International Silage Conference, a satellite workshop of the XX International Grassland Congress, July 2005, Belfast, Northern Ireland. pp. 271.

ELFERINK S.J.W.H.O., DRIEHUIS F., SPOELSTRA S.F. (1997): Improving aerobic stability of maize silage with hetero fermentative lactic acid bacteria as inoculant. Proceedings of the 8th International symposium Forage conservation. Research Institute of Animal Nutrition, Ltd. Pohorelice, 130-131.

JAMBOR V., ŠIŠKE V. (1997): The effect of the level of multi strain lactic acid bacteria inoculant on the fermentation process in maize silage. Proceedings of the 8th International symposium Forage conservation. Research Institute of Animal Nutrition, Ltd. Pohorelice, 120-121.

MC.DONALD P. (1985): Биохемия силоса. (Перевод с английского) «Агропромиздат», Москва. 
MERRY R.J., LOWES K.F., WINTERS A.L. (1997): Current and future approaches to bio control in silage. Proceedings of the 8th International symposium Forage conservation. Research Institute of Animal Nutrition, Ltd. Pohorelice, 17-27.

SPÖRNDLY R., PAULY T. (2008): Control of the fermentation process of feeds. Proceedings of the 8th International symposium Forage conservation. 3-5 September 2008, Nitra, Slovak Republik, 27-33.

ТАРАНОВ М.Т. (1982): Химическое консервирование зелёных кормов. Колос, Москва.

WEISSBACH F. (1967): Die Bestimung der Pufferkapazitat der Futterpflanzen und ihre Bedeutung der Vergarbarkeit, Aus: Tagungberichte. Nr. 92 der Deutschen Akademie der Landwirtschaftswissenschaften zu Berlin, 211-219.

WILKINSON J.M., TOIVONEN M.I. (2003): World silage-a survey of forage conservation around the world. School of Biology, University of Leeds, Leeds, LS2 9JT, United Kingdom.

Received 20 September 2009; accepted for publication 27 January 2010 